International Journal of Social Science and Economic Research

ISSN: 2455-8834

Volume:05, Issue:09 "September 2020"

\title{
AN OVERVIEW OF RURAL TOURISM AND SUSTAINABLE DEVELOPMENT
}

\author{
Kamalika Basu \\ Assistant Professor, Department of Geography \\ Dwijendralal College, Krishnagar, Nadia, West Bengal, India
}

DOI: 10.46609/IJSSER.2020.v05i09.003 URL: https://doi.org/10.46609/IJSSER.2020.v05i09.003

\begin{abstract}
This research provides an overview of sociological perspective of sustainable development of rural areas by promoting rural tourism in differential scale. It traces out the strategic approaches to the planning of rural development and identifies the problem of their overall execution. The goal of the article is to set the process of analysis of rural tourism potential and reveals the necessity of utilisation of the effective planning and marketing approach as the key factor of sustainable development of rural tourism. Determinants were assessed by micro survey conducted on North 24 Parganas, a district of West Bengal for better understanding and clarification of the findings of the paper. Apart from the literature review, statistical techniques, cartograms and SWOT analysis have been used in support of the study.
\end{abstract}

Key words: rural tourism, sustainable development, strategic planning

\section{Introduction}

Tourism encompasses a huge range of activities, natural and manmade attraction, amenities and facilities, transportation marketing and information system. Different academic research found as a tool of potential economic development particularly in rural communities. Rural tourism thus may be used as a development strategy to improve the social and economic wellbeing of the rural areas. In contemporary studies rural tourism is discussed with a positive approach for sustainable economic development of rural areas. Moreover, rural tourism particularly helps both types of small business in rural areas: those that are directly engaged in tourism e.g., farm stays, tour, tour guide etc. and those who are indirectly involved like stores, local transport etc. Thus, rural tourism may be defined as the countryside experience that encompasses a wide range of attractions and activities that take place in non urban areas. It is characterised by functionally rural, built upon small scale enterprise, open space, direct contact with the nature, traditional in nature, in terms of society, culture and practices. 
International Journal of Social Science and Economic Research

ISSN: 2455-8834

Volume:05, Issue:09 "September 2020"

\section{Objectives and Methodology}

Some of the major objectives are determined on the basis of research gaps observed in respect to the development of rural tourism are summarized below:

○ To illustrate differential types of rural tourism

○ To provide an overview of the driving forces of rural tourism in West Bengal, India

- To discuss the theoretical bases of rural tourism and sustainable development through effective planning and marketing approach

- To analyse the problems and prospect of rural tourism through micro study in North 24 Parganas, a province in West Bengal

$\circ$ And finally to identify the issues for future research and development of rural tourism.

A sample survey was conducted at North 24 Parganas, West Bengal for empirical study. Statistical techniques, mainly supporting and demanding factors are analysed, SWOT have been done and cartograms were used for interpretation of the primary data supported with a few maps.

\section{An overview of rural tourism}

Mainly three types of rural tourism are observed West Bengal, heritage tourism, ecotourism and agritourism. The main driving forces of rural tourism are as follows:

- Stresses in urban living

- Demand fuelled by media on popular places

- Increasing environmental awareness,

- Increasing number of free independent traveller (FIT),

- Rural tourism is REAL (Rewarding, Enriches spirit, provides Adventure and Learning)

- Rural areas offer fresh air, water, environment and pure scenic beauty

Benefits that we enjoy from rural tourism are in three ways:

- Economic: Rural tourism can assist job retention in services such as retailing, transport, hospitality and medical care, also to the marginal farmers, employment generation among youth population, new business opportunities

- Social: Public service improvement, revitalizing folklore, local traditional practices, preservation of historical artefacts etc.

- Environmental: Increasing the overall environmental knowledge of the visitors as well as the local people, increased use of natural and cultural elements, improvement in stability and biodiversity of the environment.

Frame of rural tourism and sustainable development: 
Sustainable development in rural tourism can be seen in terms of:

(a) Quality of life, including standard of living, public transport \& service and infrastructural development.

(b) Prosperous economy, including social economy that is based on cooperation and solidarity of the local stakeholders.

(c) Responsibility towards the natural environment.

The procedures for analysis of sustainable rural tourism demands:

(a) Evaluation of the place appropriate for rural tourism.

(b) Analysis and understanding the prospect of business and local specific risks should be identified in relation to rural tourism.

(c) Assessment of sustainable indicators of the place.

(d) Explore the attractiveness of the locality.

(e) Infrastructural requirement through questionnaire survey,

(f) Illustration of financial source and marketing strategy.

Some of the strategic plans of sustainable rural tourism that should be considered for execution are:

(a) Sustainable use of local resource

(b) Responsible and ethical approach towards artificial and natural environment

(c) Local benefits should be planned

(d) Awareness programme for stakeholders

(e) Limits must be well assessed (capacity limit, biological limit, social limit and psychological limits)

\section{Micro study on north 24 Parganas:}

A micro study has been executed in North 24 Parganas, West Bengal for better understanding of the concept. A seasonal questionnaire survey was conducted at Kochua Dham at Kochua village of Bashirhat II block and Chandraketugarh at Berachampa village of Deganga Block. 
International Journal of Social Science and Economic Research

ISSN: 2455-8834

Volume:05, Issue:09 "September 2020"

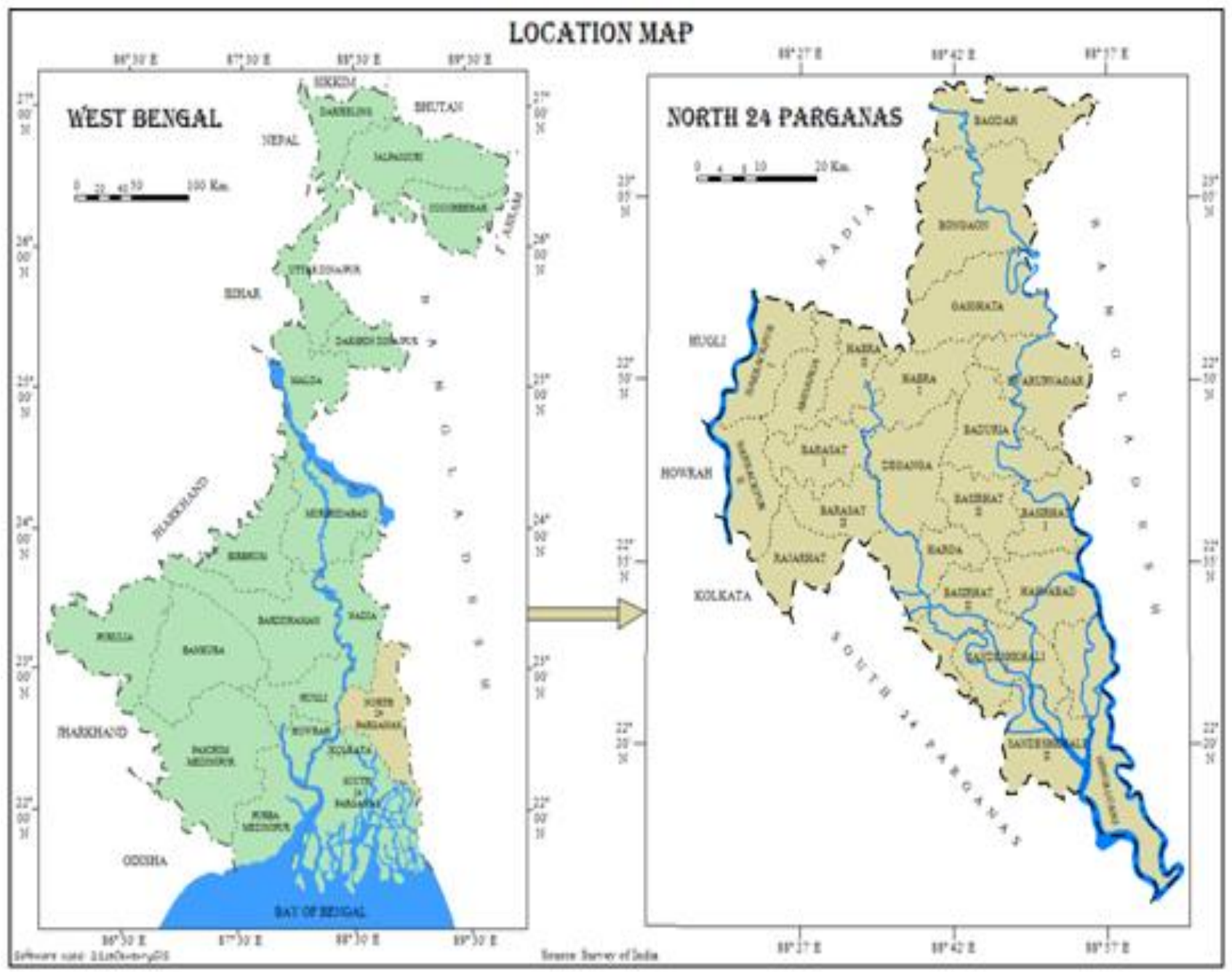




\section{International Journal of Social Science and Economic Research}

ISSN: 2455-8834

Volume:05, Issue:09 "September 2020"
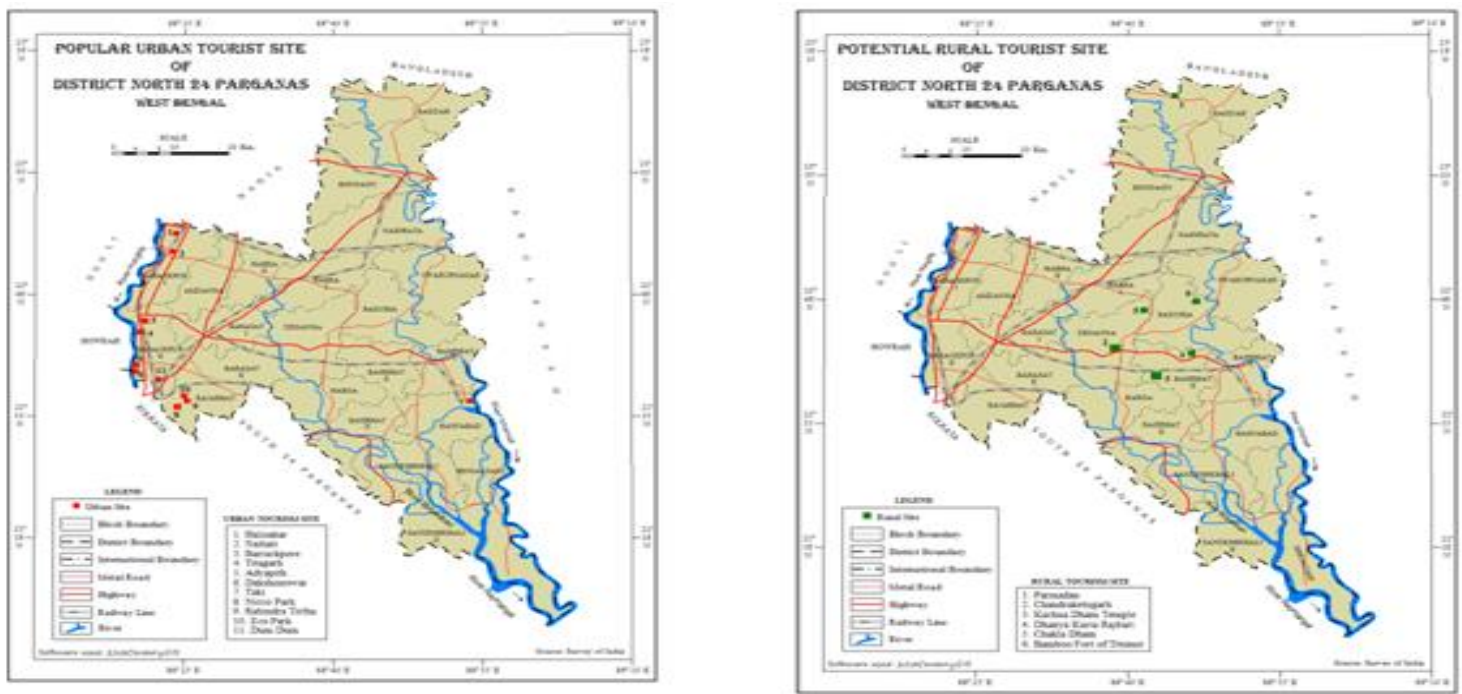

Kochua Dham is a very popular religious tourist attraction while Chandraketugarh is well known for historical background. Two different categories of rural tourist destination have been chosen for a comparative approach in the study.

\section{Result and Discussion}

Different types for respondents were surveyed during the research. Kochua Dham is a famous for Lokenath Temple where innumerable pilgrims use to come during the birthday of saint Lokenath. Tourist profile remains high here in weekends and in other holidays also.

Table 1. Types of Respondents

\begin{tabular}{|c|c|c|c|c|}
\hline \multirow{2}{*}{ Respondents } & \multicolumn{2}{|c|}{ Kochua Dham } & \multicolumn{2}{c|}{ Chandraketugarh } \\
\cline { 2 - 5 } & Frequency & $\%$ & Frequency & $\%$ \\
\hline $\begin{array}{c}\text { Members associated with hotel } \\
\text { business }\end{array}$ & 8 & 15.00 & 2 & 20 \\
\hline Packman and roadside hawkers & 6 & 11.32 & 2 & 20 \\
\hline Food stall owner & 4 & 7.54 & 1 & 10 \\
\hline Variety shop owner & 5 & 9.43 & Nil & - \\
\hline Regular tourists & 10 & 18.87 & Nil & - \\
\hline Seasonal tourists & 20 & 37.74 & 5 & 50 \\
\hline Total & 53 & 100 & 10 & 100 \\
\hline
\end{tabular}


Respondents' characteristics: Different demographic and socio economic profile of the respondents are discussed in the micro study.
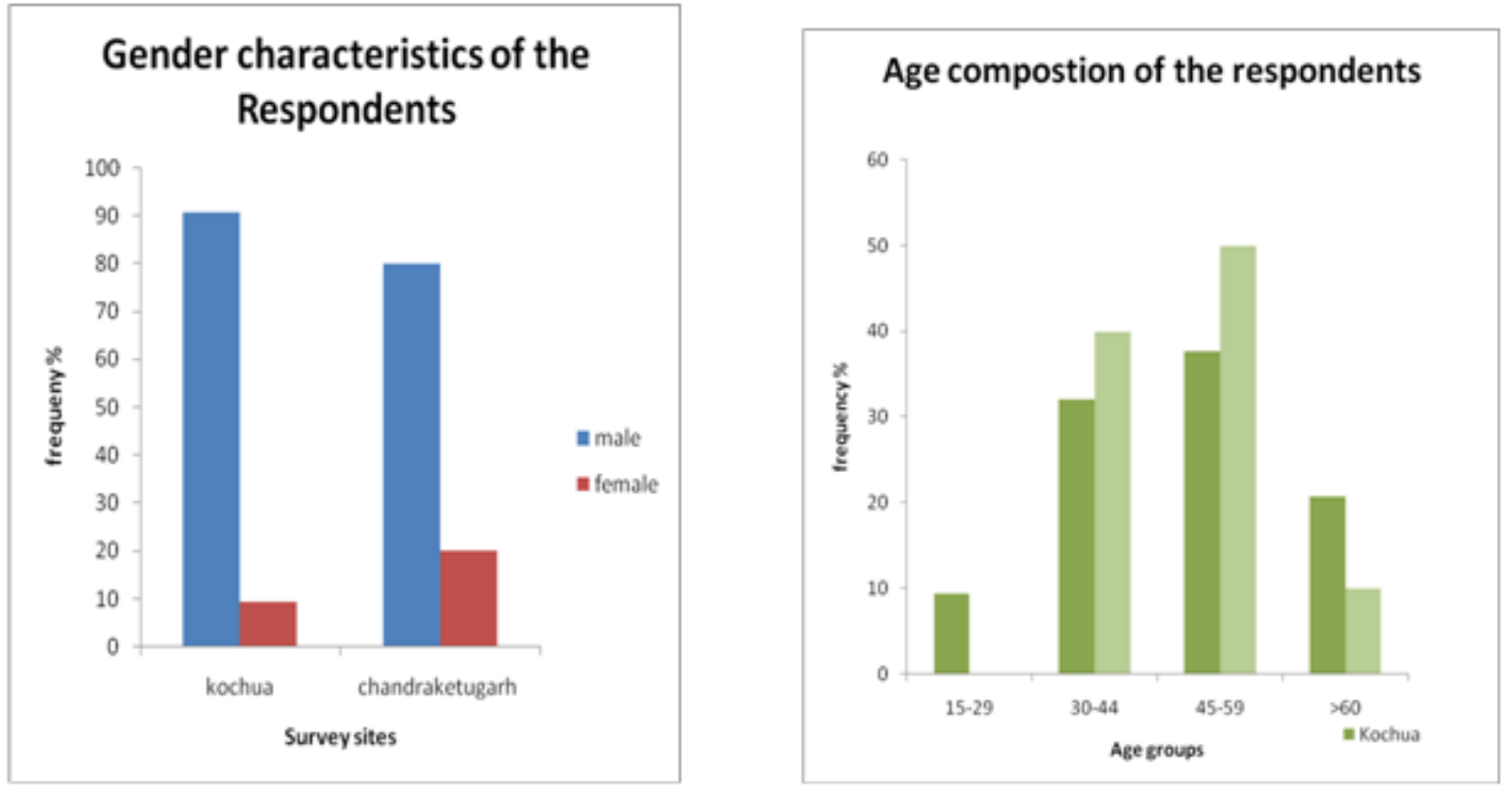

Male population is high in both Kochua (97.53\%) and Chandraketugarh (80\%). The visitors in both the places are within the age group of 30 to 60 . But during the holy birth month of Saint Lokenath pilgrims of Kochua records a huge number of aged population also.
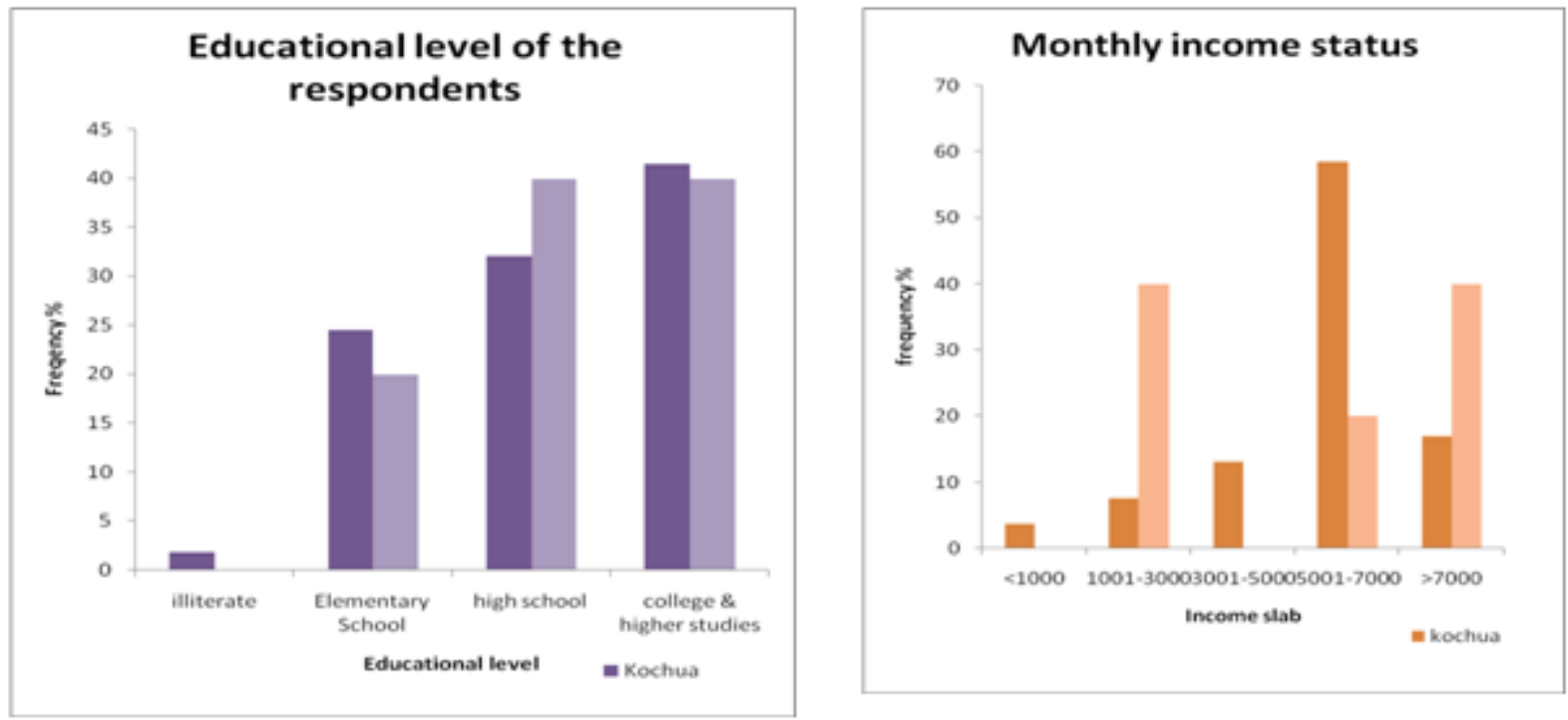
Most of the people visiting in these places are enough educated, this picture is reversed during the holy season in Kochua. But very few people are aware of the historical importance of Chandraketugarh. Kochua is much more viable place of economy generation because of the religious belief of people.

* Tourism factors identified: Basically two types of tourism factors are observed in the study area.

Table 2: Description of tourism factors

\begin{tabular}{|l|l|}
\hline Supporting Factors (SF) & Demanding factors (DF) \\
\hline $\begin{array}{l}\text { Distance and transportation of these places } \\
\text { are good. }\end{array}$ & $\begin{array}{l}\text { Exposure of Chandraketugarh is much more } \\
\text { required than Kochua. The place is } \\
\text { archaeologically important and has high } \\
\text { potential for tourism development. }\end{array}$ \\
\hline Infrastructural facilities are better in Kochua. & $\begin{array}{l}\text { Accommodation facilities are absent in both } \\
\text { the places. Particularly Chandraketugarh can } \\
\text { be exposed to the foreign tourists as it is a } \\
\text { historical place. }\end{array}$ \\
\hline $\begin{array}{l}\text { Historical value is highly appreciable in } \\
\text { Chandraketugarh while Kochua has its } \\
\text { religious value. }\end{array}$ & $\begin{array}{l}\text { Beatification and other amusements like } \\
\text { parks and gardens can boost the potentiality } \\
\text { of these places. }\end{array}$ \\
\hline $\begin{array}{l}\text { Rural traditional environment is prevailing in } \\
\text { these areas with natural scenic beauty. }\end{array}$ & $\begin{array}{l}\text { Participation of local people and involvement } \\
\text { of NGO's are required. }\end{array}$ \\
\hline
\end{tabular}

Statistical analysis of supporting factors (SF) and demanding factors (DF) of the places:

Table 3: Mean and SD of SF

\begin{tabular}{|l|l|c|c|c|c|}
\hline S1.No. & Competitive Indicators & \multicolumn{2}{|c|}{ Kochua Dham } & \multicolumn{2}{c|}{ Chandraketugarh } \\
\cline { 3 - 6 } & & Mean & SD & Mean & SD \\
\hline SF1 & Distance and transportation & 4.21 & 0.878 & 3.83 & 0.686 \\
\hline SF2 & Infrastructural facilities & 2.23 & 0.511 & 1.92 & 0.744 \\
\hline
\end{tabular}


International Journal of Social Science and Economic Research

ISSN: 2455-8834

Volume:05, Issue:09 "September 2020"

\begin{tabular}{|l|l|c|c|c|c|}
\hline SF3 & Historical and religious values & 3.62 & 0.562 & 2.94 & 0.689 \\
\hline SF4 & Rural traditional environment & 4.77 & 0.706 & 3.36 & 0.809 \\
\hline
\end{tabular}

Table 4: Mean and SD of DF

\begin{tabular}{|l|l|c|c|c|c|}
\hline S1.No. & Competitive Indicators & \multicolumn{2}{|c|}{ Kochua Dham } & \multicolumn{2}{c|}{ Chandraketugarh } \\
\cline { 3 - 6 } & & Mean & SD & Mean & SD \\
\hline DF1 & Exposures of the spots & 4.62 & 0.584 & 1.36 & 0.532 \\
\hline DF2 & Accommodation facility & 3.69 & 0.543 & 3.62 & 0.546 \\
\hline DF3 & Beautification and other amusement & 4.52 & 0.712 & 3.64 & 0.521 \\
\hline DF4 & Participation of local people & 5.75 & 0.4 .15 & 2.36 & 0.612 \\
\hline
\end{tabular}

Statistical analysis has been done for better understanding the impact of supporting and demanding factors for both of the tourist places. One sample ' $t$ ' test have been done with $95 \%$ level of confidence. The result exhibits supporting factors SF3 and SF4 are influencing of the tourism of the places while demanding factors DF1, DF3, DF4 are very much needed for sustainable tourism development of the study area.

\begin{tabular}{|l|r|r|r|r|}
\hline & $\mathrm{N}$ & \multicolumn{1}{|c|}{ Mean } & Std. Deviation & Std. Error Mean \\
\hline SF1 & 2 & 4.0200 & .26870 & .19000 \\
SF2 & 2 & 2.0750 & .21920 & .15500 \\
SF3 & 2 & 3.2800 & .48083 & .34000 \\
SF4 & 2 & 4.0650 & .99702 & .70500 \\
DF1 & 2 & 2.9900 & 2.30517 & 1.63000 \\
DF2 & 2 & 3.6550 & .04950 & .03500 \\
DF3 & 2 & 4.0800 & .62225 & .44000 \\
DF4 & 2 & 4.05500 & 2.397092 & 1.695000 \\
\hline
\end{tabular}


International Journal of Social Science and Economic Research

ISSN: 2455-8834

Volume:05, Issue:09 "September 2020"

One-Sample Test

\begin{tabular}{|c|c|c|c|c|c|c|}
\hline & \multicolumn{6}{|c|}{ Test Value $=0$} \\
\hline & \multirow[b]{2}{*}{$\mathrm{t}$} & \multirow[b]{2}{*}{$\mathrm{df}$} & \multirow[b]{2}{*}{ Sig. (2-tailed) } & \multirow[b]{2}{*}{ Mean Difference } & \multicolumn{2}{|c|}{$\begin{array}{l}95 \% \text { Confidence Interval of the } \\
\text { Difference }\end{array}$} \\
\hline & & & & & Lower & Upper \\
\hline SF1 & 21.158 & 1 & .030 & 4.02000 & 1.6058 & 6.4342 \\
\hline SF2 & 13.387 & 1 & .047 & 2.07500 & .1055 & 4.0445 \\
\hline SF3 & 9.647 & 1 & .066 & 3.28000 & -1.0401 & 7.6001 \\
\hline SF4 & 5.766 & 1 & .109 & 4.06500 & -4.8929 & 13.0229 \\
\hline DF1 & 1.834 & 1 & .318 & 2.99000 & -17.7211 & 23.7011 \\
\hline DF2 & 104.429 & 1 & .006 & 3.65500 & 3.2103 & 4.0997 \\
\hline DF3 & 9.273 & 1 & .068 & 4.08000 & -1.5107 & 9.6707 \\
\hline DF4 & 2.392 & 1 & .252 & 4.055000 & -17.48202 & 25.59202 \\
\hline
\end{tabular}

* The analysis of findings according to SWOT method are discussed below:

\section{Strengths $(S)$ :}

- Other than Kochua Dham and Chandraketugarh the existence of unique appeals of some other rural tourist areas in North 24 parganas, like Deuliya, Berachampa, Saibona village, Dhanyakuriya Rajbaria, Narkelberiya etc.

- Enriched native culture and historical significance.

- Places with rich handicrafts and artefacts.

- Some of the places are under local administrative interest in recent days.

Weaknesses (W):

- Improper internal \& external marketing.

- Lack of proper healthcare, welfare, transportation.

- Lack of proper exposure in many of the historically significant places, particularly to foreign tourists.

- Urban tourism in north 24 Parganas is given more priority. 


\section{International Journal of Social Science and Economic Research}

ISSN: 2455-8834

Volume:05, Issue:09 "September 2020"

- Lack of proper hotels and restaurants in rural waysides.

- Reluctance of private sector investments.

\section{Oppurtunities $(O)$ :}

- West Bengal tourism dept. has focussed in some of the potential places like Parmadanpur, Chandraketugarh and Dhanyakuriya Rajbari very recently.

- Possibilities of historical places to be exposed.

- Arrangements of different fairs, open air theatres.

- Possible potential sites for construction rural amusement parks.

\section{Threats $(T):$}

- Environmental pollution due to wastes and plastics materials commonly used by tourists.

- Rural land use may change up to some extent.

- Local vegetation will be damaged due to the construction of accommodation sites and other amusement parks.

- Decline of open space and free movement of local people may be interrupted.

\section{Recommendations and conclusion}

- Sustainable rural tourism demands appropriate financial sources.

- The historical places should be given priority by archaeological department.

- Motivation and campaigning is required for the involvement of local people.

- Both public and private investments are to be encouraged for employment generation.

- Proper committees should be formed for the designing, executing and monitoring of the strategic plans.

- Much more surveys and visits must be conducted by the government officials to explore the potential rural sites.

- The religious rural places which are already popular must be ecologically preserved by declaring them as plastic free zones. 
International Journal of Social Science and Economic Research

ISSN: 2455-8834

Volume:05, Issue:09 "September 2020"

Moreover with strategic development and effective planning it is necessary to have psychological up gradation and spontaneous attitude of the tourists and the local people towards an ecological as well as sustainable development of rural tourism. The slogan must be, "Think globally, and act locally".

\section{References}

- George,W., Mare,H., Reid D. (2009). Rural Tourism Development And Cultural Change. Toronto: Channel View Publication.

- Roberts, L., Hall,D. (2003). Rural Tourism And Recreation: Principles And Practise. Oxon, UK, CABI Publishing.

- Jana, N., Tarafder, S. (2012). Tourism In West Bengal: Potentialties, Problems And Prospects. https://www.researchgate.net// publication.

- Sharma, S.P.(2007). Tourism Education, Principles, Theories And Practises, Kanishka Publishers, New Delhi.

- Ghosh,B.(2002). Tourism And Travel Management, Vikas Publishing House Pvt Ltd, Mumbai.

- Chakravarti, P.K.(2007). Tourism In West Bengal: Potentials And Strategies For Development, Society And Environment And Development, Basu R, Bhaduri S, Progressive Publishers, Kolkata

- Mondal, D. (2012). Assessment of tourism carrying capacity for Hazarduari Palace Meuseum in murshidabad Municipal Town, West Bengal, Zenith, vol.2, issue 8.

- Williams, S. (2009), Tourism Geography: A New Synthesis, Routledge, London, p.81

- Chouhan, P(2012), A Study on Heritage Tourism Potentiality in Dakshin Dinajpur District of West Bengal, India, Internatiional journal for social science tomorrow, vol.1, no.5

- Banerjee, A., Ray N. and Ghosh S. (2011), Issue and Challenges of Tourism Development in West Bengal, India. International conference on management, Proceedings (2012) 